\title{
Crestal Bone Changes around Soft Tissue Level versus Bone Level Dental Implant Loaded with Single Crown: A Randomized Clinical Trial
}

\author{
Aiman O Johar
}

\begin{abstract}
Background: Crestal bone level surrounding a dental implant is a dynamic structure due to bone remodeling and possible bone loss after implant loading. The study aims to compare the bone changes around single implants $1.8 \mathrm{~mm}$ machined collar soft tissue level versus bone level implant with nonmachined collar all roughed surface placed either in the maxilla or the mandible at 3-6 years

Materials and methods: A randomized controlled clinical trial was conducted among 100 patients needing dental implants. The participants were randomly divided into two study groups; group 1 received bone level implants. Group 2 received soft tissue level implants ( $1.8 \mathrm{~mm}$ machined surface). After three months of the healing period, the implants were loaded with a screw-retained single crown. The initial measurement was done at three years and repeat measurements were recorded after six years. Statistical analysis was performed by paired sample t-test and independent sample t-test. Statistical significance was considered at $\alpha=0.05$.

Results: The bone measurements for the soft tissue level implant at three years and six years were $0.556 \pm 0.2742 \mathrm{~mm}$ and $1.172 \pm 0.6128 \mathrm{~mm}$, respectively while those for the bone level implant were $0.668 \pm 0.3178 \mathrm{~mm}$ and $1.366 \pm 0.8163 \mathrm{~mm}$, respectively. The intragroup comparison revealed that there was a statistically significant rise in the measurement at the 6-year evaluation as compared to the three-year evaluation for both the type of implants. However, the intergroup comparison revealed no statistically significant difference in the bone measurement between the two implant types at both three years and 6-year measurements.

Conclusion: There is no difference in the bone changes around single implants placed either at soft tissue level or at the bone level.

Clinical significance: The choice of implant should be based on the esthetic requirement of the patient as well as the clinician's expertise.

Keywords: Crestal bone, Microgap, Submerged implant.

World Journal of Dentistry, (2019): 10.5005/jp-journals-10015-1609
\end{abstract}

\section{INTRODUCTION}

T he past decade has experienced a significant rise in expectations, both functional and esthetic, of patients' from implantsupported restorations. Hence, the previously described standard supraepi gingival location of the crown margin (microgap/interface) is no longer acceptable from an esthetic point of view. ${ }^{1-3}$ Therefore, implants in esthetically demanding sites are placed deeper into the bone than in areas of less esthetic concern to avoid a visible titanium implant shoulder thus achieving a subgingivally located implant shoulder following healing. To obtain the desired esthetic goals, clinically driven recommendations have been devised to change the standard surgical protocol when using implants in the esthetic area. It has been recommended to create a microgap/ interface located 1-2 $\mathrm{mm}$ below the gingival margin by moving the rough/smooth implant border of non-submerged implants to slightly below the crest of the alveolar bone. ${ }^{4}$ The apical part of the relatively smooth, machined titanium surface is placed subcrestally to accomplish a subgingivally located implant shoulder. However, there is no dearth evidence from a multitude of clinical studies that additional crestal bone loss can be attributed to relatively smooth machined titanium. ${ }^{5-9}$ It has therefore been opined that, in esthetic regions or areas of limited vertical bone height, the placement of the rough/smooth implant border into a subcrestal location is not biologically favorable. Based upon experimental data, the biologic width or the supracrestal attachment is largely affected by the changes in crestal bone height around dental implants. ${ }^{10-12}$ Thus, a submerged implant placement technique might also pose a threat to the health of peri-implant soft tissues leading to recession thereby compromising the esthetics.
Department of Oral and Maxillofacial Prosthodontics, King Abdulaziz University, Faculty of Dentistry, Jeddah, Kingdom of Saudi Arabia

Corresponding Author: Aiman O Johar, Department of Oral and Maxillofacial Prosthodontics, King Abdulaziz University, Faculty of Dentistry, Jeddah, Kingdom of Saudi Arabia, Phone: +966555665565, e-mail: Aojohar@kau.edu.sa

How to cite this article: Johar AO. Crestal Bone Changes around Soft Tissue Level versus Bone Level Dental Implant Loaded with Single Crown: A Randomized Clinical Trial. World J Dent 2019;10(2):84-87.

Source of support: Nil

Conflict of interest: None

To overcome the aforementioned limitations of the submerged implant system, a new implant line was developed with a $1.8 \mathrm{~mm}$ (type A) instead of a $2.8 \mathrm{~mm}$ (type B) coronal portion with a relatively smooth, machined titanium surface. This new design offers the advantage of aligning the rough/ smooth implant border with the crest of the bone, thereby, achieving a slight subgingival location of the implant shoulder (microgap/ interface) avoiding any additional crestal bone loss. ${ }^{13}$ Our study aims to compare the bone changes around single implants 1.8 $\mathrm{mm}$ machined collar soft tissue level versus bone level implant with non-machined collar all roughed surface placed either in the maxilla or the mandible. The null hypothesis was that there is no difference in the bone changes around single implants placed either at soft tissue level or the bone level after six years of loading with the single crown.

(o) The Author(s). 2019 Open Access This article is distributed under the terms of the Creative Commons Attribution 4.0 International License (https://creativecommons. org/licenses/by-nc/4.0/), which permits unrestricted use, distribution, and non-commercial reproduction in any medium, provided you give appropriate credit to the original author(s) and the source, provide a link to the Creative Commons license, and indicate if changes were made. The Creative Commons Public Domain Dedication waiver (http://creativecommons.org/publicdomain/zero/1.0/) applies to the data made available in this article, unless otherwise stated. 


\section{Materials and methods}

Patients referred to the King Abdulaziz University hospital for single-implant treatment were considered for the study based on the following criteria:

\section{Inclusion Criteria}

Non-smoker with an age range of $18-45$ years. The subject should have one missing tooth indicated for replacement by a dental implant and no bone augmentation needed. Adequate oral hygiene and a minimum of $2 \mathrm{~mm}$ thickness of gingival tissue present at the implant site.

\section{Exclusion Criteria}

Any subject with ASA score III or presence of clinically active periodontal disease as expressed by probing pocket depths and attachment loss. Presence of periapical lesions or any other bone abnormalities. History of radiotherapy to the head and neck region or uncontrolled diabetes.

\section{Study Design}

A randomized controlled clinical trial was approved by the Medical Ethical Committee of King Abdulaziz University. Patients were recruited between 2008 and 2014. Written informed consent was obtained from all eligible patients before enrolment. One hundred patients ( 50 males and 50 females), age ranged between 18 years and 45 years were recruited for the study

\section{Study Groups}

Block randomization with an allocation ratio of 1:1 was used for assigning the patients to the two study groups. Block randomization was used to ensure equal gender distribution amongst the study groups.

- Group 1: 50 patients (25 males and 25 females) received bone level implants.

- Group 2: 50 patients (25 males and 25 females) received soft tissue level implants ( $1.8 \mathrm{~mm}$ machined surface).

\section{Intervention Procedure}

The extraction sites were allowed to heal for three months after tooth removal before placing the implants. One day before implant surgery, patients were instructed to start taking antibiotics (amoxicillin $500 \mathrm{mg}$, three times daily for seven days or clindamycin $300 \mathrm{mg}$, four times daily for seven days in case of amoxicillin allergy) and use a $0.2 \%$ chlorhexidine mouthwash (two times daily for seven days) for oral disinfection. Ibuprofen 600 mg twice daily was given as analgesic for three days. Group 1 received bone level implants. All the implants platform were surgically placed flush with the crestal bone level. After three months of the healing period, the implants were loaded with a screw-retained single crown. Group 2 received soft tissue level implants ( $1.8 \mathrm{~mm}$ machined surface). The border of the machined-rough surface was placed flush with the crestal bone leaving $1.8 \mathrm{~mm}$ of the machined collar coronal to the crestal bone. A surgical guide was used with all implants in both groups to be loaded axially. All the soft tissue level implants were loaded with a screw-retained single crown. All surgical procedures were performed by a single periodontist. The prosthetic procedure was accomplished by one prosthodontist, and all the crowns were fabricated by a single dental technician.

\section{Outcome Measure}

The primary outcome of this study was to measure the crestal bone level proximal to the implant 3 years and 6 years after implant loading by appropriate radiographic images using XP holders to standardize the exposure.

\section{Statistical Analysis}

The data was entered in Microsoft Office, Excel worksheets and analyzed using software IBM statistical package for the social sciences (SPSS) version 20.0 (IBM Statistics, SPSS, Chicago, USA). The normality of the data was assessed using the Shapiro-Wilk test while Levene's test for equality of error variances was used to analyze the homogeneity of error variances. Descriptive statistics were calculated. Independent sample t-test was used for comparison of crestal bone level measurements proximal to the implant 3 years and 6 years after implant placement and loading with a single screw-retained crown. Paired-sample t-tests were employed to evaluate intragroup differences. Statistical significance was determined at $a=0.05$.

\section{RESULts}

The current randomized controlled trial was conducted to compare the bone changes around single implants $1.8 \mathrm{~mm}$ machined collar soft tissue level versus bone level implant with non-machined collar roughened surface among hundred participants with mean age $29.35 \pm 7.11$ years.

The bone measurements for the soft tissue level implant at 3 years and 6 years was $0.556 \pm 0.2742 \mathrm{~mm}$ and $1.172 \pm 0.6128 \mathrm{~mm}$, respectively. The bone measurements for the bone level implant at 3 years and 6 years was $0.668 \pm 0.3178 \mathrm{~mm}$ and $1.366 \pm 0.8163$ $\mathrm{mm}$, respectively.

Intragroup comparison crestal bone level measurements proximal to the implant revealed that there was a statistically significant rise in the measurement at the 6-year evaluation as compared to the three-year evaluation for both the type of implants (Table 1). However, the intergroup comparison revealed no statistically significant difference in the bone measurement between the two implant types both at 3-year and 6-year measurements (Table 2).

\section{Discussion}

The study was conducted to evaluate the effect of having the microgap at the same level with the crestal bone or placing it $1.8 \mathrm{~mm}$ coronally by using soft tissue level implant, which has $1.8 \mathrm{~mm}$ of machined surface at the platform. However, there was no difference observed in the bone changes around single implants placed either

Table 1: Intragroup comparison crestal bone level measurements proximal to the implant 3 years and 6 years after implant placement

\begin{tabular}{|c|c|c|c|c|c|}
\hline Implant type & Group & $N$ & Mean $\pm S D$ & tvalue & $p$ value \\
\hline \multirow{2}{*}{ Soft tissue level } & 3 years & 50 & $0.556 \pm 0.2742$ & \multirow{2}{*}{-6.497} & \multirow{2}{*}{0.000} \\
\hline & 6 years & 50 & $1.172 \pm 0.6128$ & & \\
\hline \multirow{2}{*}{ Implant bone level } & 3 years & 50 & $0.668 \pm 0.3178$ & \multirow{2}{*}{-6.139} & \multirow{2}{*}{0.000} \\
\hline & 6 years & 50 & $1.366 \pm 0.8163$ & & \\
\hline
\end{tabular}


Bone Changes around Two Different Implant Platforms

Table 2: Intergroup comparison crestal bone level measurements proximal to the implant 3 years and 6 years after implant placement

\begin{tabular}{llllll}
\hline Evaluation & Group & $N$ & Mean $\pm S D$ & t value & $p$ value \\
\hline \multirow{2}{*}{ 3 years } & Soft tissue level & 50 & $0.556 \pm 0.2742$ & \multirow{2}{*}{0.062} \\
\hline \multirow{2}{*}{6 years } & Implant bone level & 50 & $0.668 \pm 0.3178$ & & 0.887 \\
& Soft tissue level & 50 & $1.172 \pm 0.6128$ & \multirow{2}{*}{0.182} \\
\hline
\end{tabular}

at soft tissue level or at the bone level. Hence the null hypothesis was accepted.

In the present study, the bone measurements for the soft tissue level implant at 3 years and 6 years were $0.556 \pm 0.2742$ $\mathrm{mm}$ and $1.172 \pm 0.6128 \mathrm{~mm}$, respectively while those for the bone level implant were $0.668 \pm 0.3178 \mathrm{~mm}$ and $1.366 \pm 0.8163 \mathrm{~mm}$, respectively. This finding was similar to those of Hanggi et al. ${ }^{13}$ who reported crestal bone levels about $0.3 \mathrm{~mm}$ below the rough/ smooth implant border for type A implants, and about $0.5 \mathrm{~mm}$ for type B implants, respectively, thereby concluding that crestal bone levels are influenced by the location of the rough/smooth implant border in relation to the crest of the bone.

Dental Implants are widely used in prosthetic dentistry to replace lost or congenitally missing teeth. ${ }^{14}$ Nowadays, the concern of success is shifted from implant survival to the quality of implant survival regarding aesthetic and proper function. ${ }^{15,16}$

The esthetic outcome is obtained by several factors. Appropriate selection of implant type, diameter, and position "tooth-implant distance," Crown dimensions and height of proximal contact. ${ }^{17}$ Other important factors such as peri-implant soft tissue that should mimic the physiologic gingival architecture with harmonious mucosal color and texture. Dental papilla height is related to a crestal bone level considered an important periimplant hard tissue factor. ${ }^{18}$

Criteria of success are that all dental implants undergo physiological marginal bone loss (MBL) vertically and horizontally after integration and through a time of function up to $1-1.5 \mathrm{~mm}$ within the first year of loading implant and restoration, followed by $\leq 0.2 \mathrm{~mm}$ annually. ${ }^{19}$ The amount of bone loss is determined by different physiologic changes which are postsurgical trauma, the result of alveolar bone remodeling to the functional load, the initiation of biologic width recently known as supracrstal attachment, the presence and size of a microgap. ${ }^{20}$

It has been reported that placing the microgap in a subcrestal position (at least $1 \mathrm{~mm}$ ) may be associated with a higher amount of bone loss during the remodeling process as compared to an epi- or supracrestal implant. However, despite a more pronounced bone remodeling, the subcrestal positioning of the microgap may help to retain the bony coverage of the rough surface. ${ }^{21,22} \mathrm{~A}$ slight bone gain of $0.19 \mathrm{~mm}$ was noted for an implant placed with the neck $1 \mathrm{~mm}$ supra to the crestal bone in a study by Cochran et al. ${ }^{21,22}$ Hermann et al. demonstrated no significant difference in the amount of crestal bone could be attributed to the size of the microgap, but welding the abutment to the implant with a laser resulted in significantly lower bone resorption. ${ }^{23}$ The movement between abutment and implant in addition to microbial contamination seemed then to influence that crestal bone resorption. ${ }^{23} \mathrm{~A}$ former study conducted by Cochran et al. compared the one-piece implant system placed in anterior maxilla and mandible with different level of placement. Rough-smooth boarder 2.8 standard ITI implant located in an average $1.3 \mathrm{~mm}$ apical to the alveolar crest in the maxilla as a baseline. While in the mandible, implants were placed supracrestal. Amount of peri-implant bone loss from the implant shoulder to the first bone to implant contact $(\mathrm{BIC})$ radiographically according to its position was on average of $3.2 \mathrm{~mm}, 0.68 \mathrm{~mm}$, respectively during the first 6 months. ${ }^{19}$ Another study that was conducted by Alomrani et al. compared the bone loss around implant placed in canine with $2.8 \mathrm{~mm}$ machined collar to implant roughened with a nonmachined collar placed at the different level of alveolar ridges under unloaded conditions for six months. The result was less bone loss of $0.4 \mathrm{~mm}$ of the roughened collar, while $0.69 \mathrm{~mm}$ in $2.8 \mathrm{~mm}$ machined collar when both implants were placed at the same level. ${ }^{20}$ The further study analyzed histologically by Hermann et al. to support Alomrani compared machined collar and nonmachined collar implant placed on different levels in relation to the crestal bone. It concluded that crestal bone loss could be significantly reduced when placing a completely roughened nonmachined collar implant $1 \mathrm{~mm}$ above the crestal bone, while the machined collar implant exhibited more bone loss when placed at the same level as a nonmachined collar. ${ }^{24}$

The results of this study indicate that there is no additional crestal bone loss when placing implants with their rough/ smooth implant border at the bone crest level when compared to a bone level implant 6 years postimplant placement and loading. This may be of importance in areas of esthetic concern based upon the principle of the biologic width (supracrestal attachment), ${ }^{13}$ eventually reducing the risk of an exposed metal implant shoulder.

Our study was limited to a single implant loaded with screwretained crown and bone changes measurement was performed with a regular radiograph. However, future study should include multiple implants connected with rigid connector and bone loss measurement with cone beam computed tomography CBCT.

\section{Conclusion}

It can be concluded that there is no difference in the bone changes around single implants for both design soft tissue level or bone level after 6 years of loading if the rough surface was placed flush with the crestal bone.

\section{Clinical significance}

Both designs have almost the same effect on the crestal bone level if strict implant placement and loading protocol is followed. Therefore, the clinician must take into consideration the esthetic concern along with the tissue health of the patients while choosing the implant systems for restoration.

\section{Future Study Design}

Axial loading with straight abutments was selected in our study. We would like to investigate the effect of nonaxial loading on crestal bone loss by placing an angulated abutment and compare it to the axial loading.

\section{References}

1. Buser DA, Schroeder A, Sutter F, et al. The new concept of ITI hollow-cylinder and hollow-screw implants: Part 2. Clinical aspects, 
indications, and early clinical results. Int J Oral Maxillofac Implants 1988;3:173-181.

2. Sutter F, Schroeder A, Buser DA. The new concept of ITI hollowcylinder and hollow-screw implants: Part 1. Engineering and design. Int J Oral Maxillofac Implants 1988;3:161-172.

3. Buser D, Weber HP, Brägger U. The treatment of partially edentulous patients with ITI hollow-screw implants: Presurgical evaluation and surgical procedures. Int J Oral Maxillofac Implants 1990;5:165-175.

4. Hess $D$, Buser D, Dietschi $D$, et al. Esthetic single-tooth replacement with implants: A team approach. Quintessence Int 1998;29:77-86

5. Al-Sayyed A, Deporter DA, Pilliar RM, et al. Predictable crestal bone remodelling around two porous-coated titanium alloy dental implant designs. A radiographic study in dogs. Clin Oral Implants Res 1994;5:131-141.

6. Hermann JS, Cochran DL, Nummikoski PV, et al. Crestal bone changes around titanium implants. A radiographic evaluation of unloaded nonsubmerged and submerged implants in the canine mandible. J Periodontol 1997;68:1117-1130.

7. Hermann JS, Buser D, Schenk RK, et al. Crestal bone changes around titanium implants. A histometric evaluation of unloaded nonsubmerged and submerged implants in the canine mandible. J Periodontol 2000;71:1412-1424.

8. Hermann JS, Schoolfield JD, Nummikoski PV, et al. Crestal bone changes around titanium implants. A methodologic study comparing linear radiographic with histometric measurements. Int J Oral Maxillofac Implants 2001;16:475-485.

9. Hämmerle $\mathrm{CH}$, Brägger $\mathrm{U}$, Bürgin W, et al. The effect of subcrestal placement of the polished surface of ITI implants on marginal soft and hard tissues. Clin Oral Implants Res 1996;7:111-119.

10. Cochran DL, Hermann JS, Schenk RK, et al. Biologic width around titanium implants. A histometric analysis of the implanto-gingival junction around unloaded and loaded nonsubmerged implants in the canine mandible. J Periodontol 1997;68:186-198.

11. Hermann JS, Buser D, Schenk RK, et al. Biologic width around titanium implants. A physiologically formed and stable dimension over time. Clin Oral Implants Res 2000;11:1-11.

12. Hermann JS, Buser D, Schenk RK, et al. Biologic width around one- and two-piece titanium implants. A histometric evaluation of unloaded nonsubmerged and submerged implants in the canine mandible. Clin Oral Implants Res 2001;12:559-571

13. Hänggi MP, Hänggi DC, Schoolfield JD, et al. Crestal bone changes around titanium implants. Part I: a retrospective radiographic evaluation in humans comparing two non-submerged implant designs with different machined collar lengths. Journal of Periodontology. 2005 May;76(5):791-802.

14. Den Hartog L, Meijer HJA, Stegenga B, et al. Single implants with different neck designs in the aesthetic zone: a randomized clinical trial. Clin Oral Implants Res 2011;22:1289-1297.

15. Den Hartog L, Slater JJ, Vissink A, et al. Treatment outcome of immediate, early and conventional single-tooth implants in the aesthetic zone: a systematic review to survival, bone level, soft-tissue, aesthetics and patient satisfaction. J Clin Periodontol 2008;35:10731086.

16. Belser UC, Grutter L, Vailati F, et al. Outcome evaluation of early placed maxillary anterior single-tooth implants using objective esthetic criteria: a cross-sectional, retrospective study in 45 patients with a 2- to 4-year follow-up using pink and white esthetic scores. $J$ Periodontol 2009;80:140-151.

17. Akoğlu Vanlığlu B, Kahramanoğlu E, Yıldız C, et al. Esthetic outcome evaluation of maxillary anterior single-tooth bone-level implants with metal or ceramic abutments and ceramic crowns. Int J Oral Maxillofac Implants 2014 Sep 1;29(5).

18. Chang $\mathrm{M}$, Wennström JL. Longitudinal changes in tooth/singleimplant relationship and bone topography: an 8-year retrospective analysis. Clin Implants Dent Rel Res 2012;14(3):388-394.

19. Hartman GA, Cochran DL. Initial implant position determines the magnitude of crestal bone remodeling. J Periodontol 2004;75(4):572577.

20. Valderrama P, Bornstein MM, Jones $A A$, et al. Effects of Implant Design on Marginal Bone Changes Around Early Loaded, Chemically Modified, Sandblasted Acid-Etched-Surfaced Implants: A Histologic Analysis in Dogs. J Periodontol 2011;82(7):1025-1034.

21. Schwarz F, Hegewald A, Becker J. Impact of the implant-abutment connection and positioning of the machined collar/microgap on crestal bone level changes: a systematic review. Clin Oral Implants Res 2014;25(4):417-425.

22. Cochran DL, Bosshardt DD, Grize $L$, et al. Bone response to loaded implants with non-matching implant-abutment diameters in the canine mandible. J Periodontol 2009;80(4):609-617.

23. Hermann JS, Schoolfield JD, Schenk RK, et al. Influence of the size of the microgap on crestal bone changes around titanium implants. A histometric evaluation of unloaded non-submerged implants in the canine mandible. J Periodontol 2001; 72(10):1372-1383.

24. Hermann JS, Jones AA, Bakaeen LG, et al. Influence of a machined collar on crestal bone changes around titanium implants: a histometric study in the canine mandible. J Periodontol 2011;82(9):1329-1338. 